\title{
Modellization of Metal Hydride Canister for Hydrogen Storage
}

\author{
By R. Maceiras ${ }^{1}$, V. Alfonsin ${ }^{1}$, A. Cancela ${ }^{2}$, A. Sanchez ${ }^{2}$
}

\begin{abstract}
Hydrogen shows very interesting features for its use on-board applications as fuel cell vehicles. This paper presents the modelling of a tank with a metal hydride alloy for on-board applications, which provides good performance under ambient conditions. The metal hydride contained in the tank is Ti0.98Zr0.02V0.43Fe0.09Cr0.05Mn1.5. A two-dimensional model has been performed for the refuelling process (absorption) and the discharge process (desorption). For that, individual models of mass balance, energy balance, reaction kinetics and behaviour of hydrogen gas has been modelled. The model has been developed under Matlab / SimulinkC environment. Finally, individual models have been integrated into a global model, and simulated under ambient conditions. With the aim to analyse the temperature influence on the state of charge and filling and emptying time, other simulations were performed at different temperatures. The obtained results allow to conclude that this alloy offers a good behaviour with the discharge process under normal ambient conditions.
\end{abstract}

Keywords: Hydrogen storage; metal bydrides; fuel cell; simulation; board applications

\section{Introduction}

The use of hydrogen as substitute for carbon based fuels is of increasing interest (Jiang et al., 2005). It can be stored in different ways, such as pressurized gas, cryogenic liquid, solid fuel as chemical or physical combination with materials (metal hydrides, complex hydrides and carbon materials), or produced on-board (Ogden, 1999). For this reason, hydrogen shows very interesting features for its use on-board applications as fuel cell vehicles. One of the greatest problems for the implementation of hydrogen energetic systems is the difficulty to store, especially in on-board systems. This problem can be solved using metal hydrides since they have been established as excellent media for on-board or stationary hydrogen storage (Bhuiya, Kumar, \& Kim, 2015).

Metal hydride for hydrogen storage has been researched in the last decade (Eberle, Arnold, \& von Helmolt, 2006; Latroche, 2004). Some studies indicated that metal hydrides can be used to store hydrogen under moderate conditions of temperature and pressure (Sakintuna, Lamari-Darkrim, \& Hirscher, 2007). The use of metal hydrides has the following advantages: safety, good storage properties and high volume-efficient storage capacity for on-board applications. Moreover, metal hydrides are the most compact way to store hydrogen. Hydrogen storage in metal hydrides depends on different parameters and consists of several mechanistic steps. The desirable properties are high hydrogen storage capacity, flat plateau, low hysteresis, fast reaction rates and good thermal stability (Sharma, Anil Kumar, \& Srinivasa Murthy, 2015).

Some researches have been conducted on the metal hydrides for improving adsorption/desorption properties based on hydrogen- storage capacity, kinetics and thermal properties (Bououdina, Grant, \& Walker, 2006). Taking into account that absorption and desorption processes are exothermic and endothermic, respectively, metal hydride storage systems can be engineered to supply heated or cooled air, being a suitable option in designing

${ }^{2}$ Chemical Engineering Department, EEI, University of Vigo, 36310 Vigo, Spain . 
thermochemical heat storage system or in energy systems applications such as metal hydride batteries and fuel cells. However, it is known that the performance of hydrogen charge to/discharge from metal hydride depends on the heat transfer, mass transfer and kinetic reactions (Laurencelle \& Goyette, 2007; Souahlia et al., 2011)3. Then, the design of optimized canister needs to predict transient heat and mass transfer in the metal hydride. Some researchers are often employed heat exchangers to accelerate absorption/desorption rate in metal hydride canister (MacDonald \& Rowe, 2006a; Mellouli, Askri, Dhaou, Jemni, \& Ben Nasrallah, 2007; Mellouli, Askri, Dhaou, Jemni, \& Ben Nasrallah, 2009; Mellouli, Dhaou, Askri, Jemni, \& Ben Nasrallah, 2009). However, some metal hydride can be effective at ambient conditions.

In this paper, a metal hydride hydrogen storage system has been modelled under Matlab/Simulink ${ }^{\circledR}$ environment. Several individual models have been developed: mass and energy balance, desorption reaction kinetics and the hydrogen gas behaviour. Finally, global model has been optimized in order to adapt it to the commercial metal hydride alloy of $\mathrm{Ti}_{0.98} \mathrm{Zr}_{0.02} \mathrm{~V}_{0.43} \mathrm{Fe}_{0.09} \mathrm{Cr}_{0.05} \mathrm{Mn}_{1.5}$. This alloy offers a good behaviour with the discharge process under normal ambient conditions.

\section{Metal Hydride System Discharge Model}

Desorption of hydrogen in metal hydride canisters is an endothermic reaction. When a fuel cell demands power, the hydrogen flows from the canister to the fuel cell. While this discharge process is taking place, the canister temperature is reduced. The temperature drop brakes the desorption reaction. And this effect depends mainly on the metal hydride alloy, the ambient temperature and the fuel cell power demanded. For this study, a commercially metal hydride canister of Ovonic Hydrogen System LLC is selected. The alloy contained in this vessel was determined as type $\mathrm{AB}_{2}$ of metal hydride. Other authors determined this alloy as $\mathrm{Ti}_{0.98} \mathrm{Zr}_{0.02} \mathrm{~V}_{0.43} \mathrm{Fe}_{0.09} \mathrm{Cr}_{0.05} \mathrm{Mn}_{1.5}$ (Sandrock, 1999). The main properties for this material are shown in Table 1 (MacDonald \& Rowe, 2006b).

Table 1: Properties of $\mathrm{Ti}_{0.98} \mathrm{Zr}_{0.02} \mathrm{~V}_{0.43} \mathrm{Fe}_{0.09} \mathrm{Cr}_{0.05} \mathrm{Mn}_{1.5}$

\begin{tabular}{lc}
\hline Properties & Value \\
\hline Crystalline density & $5577 \mathrm{~kg} / \mathrm{m}^{3}$ \\
Empty Density & $5500 \mathrm{~kg} / \mathrm{m}^{3}$ \\
Specific heat & $490 \mathrm{~J} / \mathrm{kg} \cdot \mathrm{K}$ \\
Effective thermal conductivity & $1.4 \mathrm{~W} / \mathrm{m} \cdot \mathrm{K}$ \\
Permeability & $10^{-8} \mathrm{~m}^{2}$ \\
Reaction heat of formation & $-1.359 \cdot 10^{7}$ \\
Porosity & 0.43 \\
\hline
\end{tabular}

In order to test the behaviour of this kind of hydrogen storage for on-board applications, a metal hydride canister model was performed, and finally adapted to this alloy. Consequently, it was checked for several fuel cell power values and compared with the manufacturer's datasheet. Fig. 1 shows the model developed in this paper. A model of a canister with the selected alloy of metal hydride is included in it. 


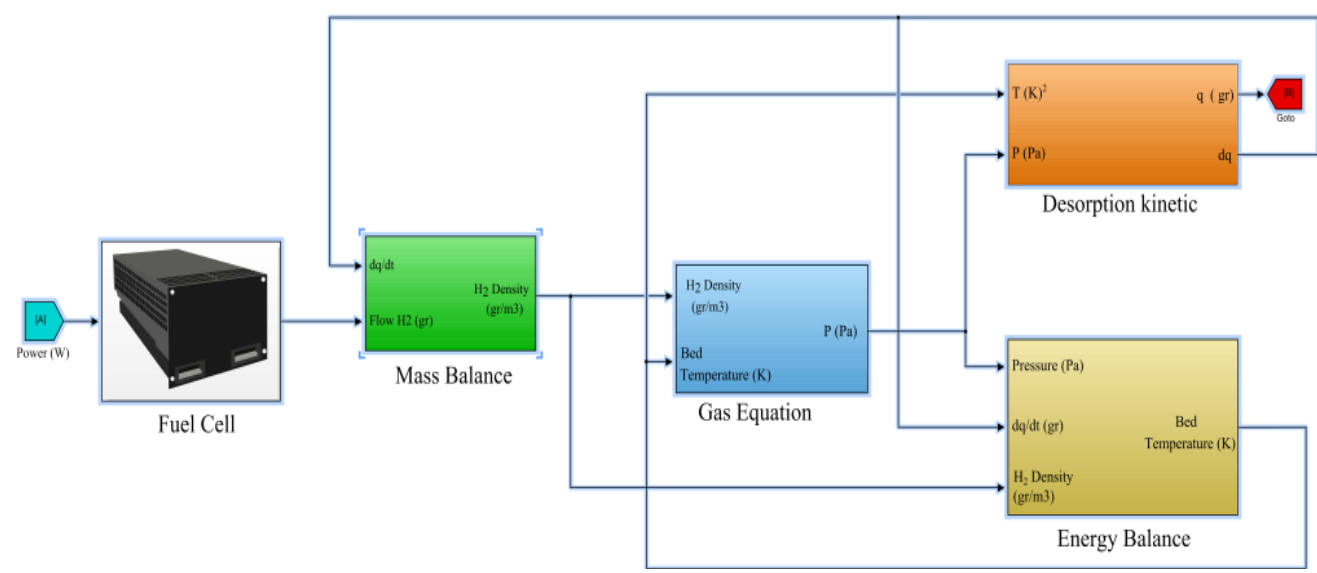

Fig. 1: Global model: Fuel Cell and canister model (mass balance, gas equation, kinetic of reaction and energy balance)

For this task, mass balance, gas equation, kinetic of reaction and energy balance, are used. Moreover, in order to estimate the fuel cell consumption, a model of fuel cell is also included.

\subsection{Fuel cell model consumption}

A model for the fuel cell consumption was developed to obtain $\mathrm{H}_{2}$ flow as a function of the fuel cell power demanded. An equation to model the hydrogen intake as a function of power demanded by the fuel cell (by the motor and the auxiliary systems) can be used.

$H_{2 \text { usage }}=\frac{P_{\text {electric }}}{2 V_{c} F}$

Thus, this equation was obtained considering the simple reaction stoichiometry (Larminie \& Dicks, 2003) which depends of power demanded by the fuel cell $\left(P_{\text {electric }}\right)$, the Faraday's Constant $(F)$ and the stack potential $\left(V_{c}\right)$. It yields the hydrogen mass flux $\left(H_{2 \text { usage }}\right)$, in moles per second, which makes possible to know the hydrogen consumption at each moment.

\subsection{Gas equation modelization}

The original form of Redlich-Kwong equation of state was used to predict the behaviour of stored hydrogen in the canisters (Djordjević, Mihajlov, Grozdanić, Tasić, \& Horvath, 1977). $P=\frac{R T}{v-b}-\frac{a}{\left(v(v+b) T^{0.5}\right.}$

Where $R$ is the universal gas constant, $T$ the bed temperature, $v$ the molar volume, $a$ is a constant that corrects for attractive potential of molecules, and $b$ is a constant that corrects for volume. The inputs for this model were temperature $(T)$ and pressure $(P)$. The $a, b$ constants were obtained from the critical temperature $\left(T_{c}=32.23 \mathrm{~K}\right)$ and pressure $\left(P_{c}=131600 \mathrm{~Pa}\right)$ of $\mathrm{H}_{2}$.

\subsection{Mass balance model}

The mass balance for discharge (desorption process) was estimated with the following equation (Raju, Ortmann, \& Kumar, 2010):

$\frac{d \rho}{d t}=\frac{-(1-\varepsilon) \rho_{s} f V_{\text {bed }} \frac{d q}{d t}-m_{\text {out }}}{\varepsilon f V_{\text {bed }}}$ 
Where $\rho_{s}$ is the crystalline density, $f$ is the ratio between the volume of the heat transfer canister and the total volume of the bed, $V_{\text {bed }}$ is the volume of the bed, $\varepsilon$ is the porosity, $m_{\text {out }}^{\cdot}$ is the mass of hydrogen flowing from the system, and $q$ is the weight fraction of $\mathrm{H}_{2}$ desorbed.

\subsection{Desorption kinetic model} al., 2010):

The kinetic of desorption process is taken into account through this expression (Raju et

$\frac{d q}{d t}=C_{a} e^{\left(-E_{a} / R T\right)} \ln \left(\frac{P}{P_{e q}}\right)\left(q_{\max }-q\right)$

Where $C_{a}$ is the Arrhenius rate constant, $E_{a}$ the activation energy, $P$ the bed pressure and $P_{e q}$ is the equilibrium pressure obtained through the van't Hoff equation, which was implemented as a Matlab® function (Muthukumar \& Satheesh, 2013).

\subsection{Energy Balance Model}

In order to estimate the rate of the heat exchanged during the desorption process, an energy balance is performed. For this purpose, heat transfer phenomena are taken into account. Table 2 summarizes the rates of heat transfer considered in this model. With the purpose of studying the metal hydride behaviour under several conditions of temperature, canister was submerged in a thermostatic bath (MacDonald \& Rowe, 2006b; Raju et al., 2010).

Table 2: Energy balance for the discharge process

\begin{tabular}{lc}
\hline $\mathbf{H}_{2}$ discharge phenomena & Energy model equation \\
\hline Rate of heat in the desorption process & $\frac{(1-\varepsilon)}{\varepsilon} \rho_{s} \Delta H \frac{d q}{d t}$ \\
Rate of heat of gas expansion & $\left(\frac{P}{\rho}\right) \frac{m_{s}}{\varepsilon f V_{\text {bed }}}$ \\
Rate of heat transfer from thermostatic bath to the bed & $\frac{T-T_{\text {ext }}^{2}}{\frac{R_{b e d}}{2 h_{c}}+\left(\frac{\varepsilon R_{b e d}^{2}}{4 k}\right)}$ \\
Rate of heat accumulated in the metal hydride bed & $\left(\rho C_{V, g}+\frac{(1-\varepsilon)}{\varepsilon} q \rho_{s} C_{V, g}+\frac{(1-\varepsilon)}{\varepsilon} \rho_{S} C_{P, s}\right) \frac{d T}{d t}$ \\
\hline
\end{tabular}

\section{Simulation}

Finally several simulations were made for a canister with this alloy. The metal hydride canister used was an Ovonic ${ }^{\circledR}$ 85G250B. It can contain $80 \mathrm{gr}$ of hydrogen (900 std. litters). The operating temperature for this commercial canister is $0-75^{\circ} \mathrm{C}$. The external case is aluminium, and it was supposed submerged under water in a thermostatic bath with a temperature of $15^{\circ} \mathrm{C}$.

This temperature was selected in order to obtain similar results than manufacturer's data sheet (supposedly under flowing air at $6 \mathrm{~m} / \mathrm{sec}$ ). Fig. 2 shows several fuel cell stack power and the autonomy of this commercial canister. In it, simulated values and the manufactured data are compared, obtaining a good approximation, although the manufacturer does not specify the air flow temperature. In order to check the accuracy of this model with more precision, compare the simulation results with experimental data would be recommended. 


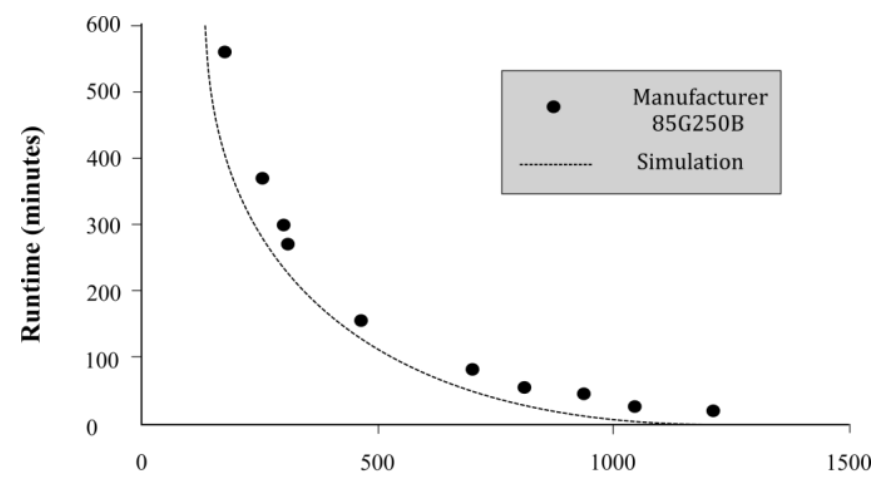

Fuel cell stack power $(\mathbf{W})$

Fig. 2: Autonomy of Ovonic $₫$ canister under flow air conditions and submerged at $15^{\circ} \mathrm{C}$

\section{Conclusions}

In this paper, the modellization of metal hydride canister for hydrogen storage was carried out. The obtained results allow to conclude that this alloy offers a good behaviour with the discharge process under normal ambient conditions.

\section{References}

Bhuiya, M. M. H., Kumar, A., \& Kim, K. J. (2015). Metal hydrides in engineering systems, processes, and devices: A review of non-storage applications. International Journal of Hydrogen Energy, 40(5), 2231 2247. doi:http://dx.doi.org/10.1016/j.ijhydene.2014.12.009

Bououdina, M., Grant, D., \& Walker, G. (2006). Review on hydrogen absorbing materials—structure, microstructure, and thermodynamic properties. International Journal of Hydrogen Energy, 31(2), 177 182. doi:http://dx.doi.org/10.1016/i.ijhydene.2005.04.049

Djordjević, B. D., Mihajlov, A. N., Grozdanić, D. K., Tasić, A. Ž, \& Horvath, A. L. (1977). Applicability of the redlich-kwong equation of state and its modifications to polar gases. Chemical Engineering Science, 32(9), 1103-1107. doi:http://dx.doi.org/10.1016/0009-2509(77)80149-8

Eberle, U., Arnold, G., \& von Helmolt, R. (2006). Hydrogen storage in metal-hydrogen systems and their $\begin{array}{lllll}\text { derivatives. Journal of Power } & \text { Sources, } & \text { 154(2), }\end{array}$ doi:http://dx.doi.org/10.1016/i.jpowsour.2005.10.050

Jiang, Z., Dougal, R. A., Liu, S., Gadre, S. A., Ebner, A. D., \& Ritter, J. A. (2005). Simulation of a thermally coupled metal-hydride hydrogen storage and fuel cell system. Journal of Power Sources, 142(1-2), 92102. doi:http://dx.doi.org/10.1016/j.jpowsour.2004.09.029

Larminie, J., \& Dicks, A. (2003). Fuel cell systems explained. Oxford: John Wiley \& Sons Ltd.

Latroche, M. (2004). Structural and thermodynamic properties of metallic hydrides used for energy storage 2 . Journal of Physics and Chemistry of Solids, 65(2-3), 517-522. doi:http://dx.doi.org/10.1016/j.jpcs.2003.08.037

Laurencelle, F., \& Goyette, J. (2007). Simulation of heat transfer in a metal hydride reactor with aluminium foam. International Journal of Hydrogen Energy, 32(14), 2957-2964. doi:http://dx.doi.org/10.1016/j.ijhydene.2006.12.007

MacDonald, B. D., \& Rowe, A. M. (2006a). Impacts of external heat transfer enhancements on metal hydride storage tanks. International Journal of Hydrogen Energy, 31(12), 1721-1731. doi:http://dx.doi.org/10.1016/i.iihydene.2006.01.007

MacDonald, B. D., \& Rowe, A. M. (2006b). A thermally coupled metal hydride hydrogen storage and fuel cell system. Journal of Power Sources, 161(1), 346-355. doi:http://dx.doi.org/10.1016/i.jpowsour.2006.04.018 
Mellouli, S., Askri, F., Dhaou, H., Jemni, A., \& Ben Nasrallah, S. (2007). A novel design of a heat exchanger for a metal-hydrogen reactor. International Journal of Hydrogen Energy, 32(15), 3501-3507. doi:http://dx.doi.org/10.1016/i.ijhydene.2007.02.039

Mellouli, S., Askri, F., Dhaou, H., Jemni, A., \& Ben Nasrallah, S. (2009). Numerical study of heat exchanger effects on charge/discharge times of metal-hydrogen storage vessel. International Journal of Hydrogen Energy, 34(7), 3005-3017. doi:http://dx.doi.org/10.1016/j.ijhydene.2008.12.099

Mellouli, S., Dhaou, H., Askri, F., Jemni, A., \& Ben Nasrallah, S. (2009). Hydrogen storage in metal hydride tanks equipped with metal foam heat exchanger. International Journal of Hydrogen Energy, 34(23), 9393-9401. doi:http://dx.doi.org/10.1016/i.ijhydene.2009.09.043

Muthukumar, P., \& Satheesh, A. (2013). Analysis of crossed van't hoff metal hydride based heat pump. International Journal of Hydrogen Energy, 38(26), 11415-11420. doi:http://dx.doi.org/10.1016/j.ijhydene.2013.06.070

Ogden, J. M. (1999). Developing an infrastructure for hydrogen vehicles: A southern california case study. International Journal of Hydrogen Energy, 24(8), 709-730. doi:http://dx.doi.org/10.1016/S0360$\underline{3199(98) 00131-1}$

Raju, M., Ortmann, J. P., \& Kumar, S. (2010). System simulation model for high-pressure metal hydride hydrogen storage systems. International Journal of Hydrogen Energy, 35(16), 8742-8754. doi:http://dx.doi.org/10.1016/j.ijhydene.2010.05.024

Sakintuna, B., Lamari-Darkrim, F., \& Hirscher, M. (2007). Metal hydride materials for solid hydrogen storage: A review. International Journal of Hydrogen Energy, 32(9), 1121-1140. doi:http://dx.doi.org/10.1016/i.ijhydene.2006.11.022

Sandrock, G. (1999). A panoramic overview of hydrogen storage alloys from a gas reaction point of view. Journal of Alloys and Compounds, 293-295(0), 877-888. doi:http://dx.doi.org/10.1016/S0925$\underline{\text { 8388(99)00384-9 }}$

Sharma, V. K., Anil Kumar, E., \& Srinivasa Murthy, S. (2015). Influence of dynamic operating conditions on the performance of metal hydride based solid sorption cooling systems. International Journal of Hydrogen Energy, 40(2), 1108-1115. doi:http://dx.doi.org/10.1016/j.ijhydene.2014.11.084

Souahlia, A., Dhaou, H., Askri, F., Sofiene, M., Jemni, A., \& Ben Nasrallah, S. (2011). Experimental and comparative study of metal hydride hydrogen tanks. International Journal of Hydrogen Energy, 36(20), 12918-12922. doi:http://dx.doi.org/10.1016/i.ijhydene.2011.07.022 